\title{
The list of cyanobacterial species of the Czech Republic to the end of 2009
}

\author{
Jan KašTovskÝ*1, Tomáš Hauer ${ }^{1,2}$, Jiří KoMÁReK ${ }^{1,2} \&$ Olga SkÁcelovÁ ${ }^{3}$ \\ ${ }^{1}$ Faculty of Science, University of South Bohemia, Branišovská 31, České Budějovice 37005, Czech Republic. \\ ${ }^{2}$ Institute of Botany, Czech Academy of Sciences, Dukelská 135, Třeboň 37982, Czech Republic. \\ ${ }^{3}$ Moravian Museum, Zelný trh 6, Brno 65937, Czech Republic. \\ *corresponding author email: hanys@prf.jcu.cz
}

\begin{abstract}
This article summarizes up to date knowledge of occurrence of Cyanobacteria in the Czech Republic; abundance and ecological characteristics are provided for each species. The list does not contain non-verified findings and questionable or unclear taxa, names of the species and synonymy is in agreement with modern nomenclatural system. Based on these criteria, a total of 505 species have been recorded for the area since 1892 , whereas occurrence of only 392 species is known recently. This indicates clear trend towards the decrease of the number of the taxa. Most of the extinct and potentially endangered species are likely of the oligotrophic standing waters and wetlands, as these habitats are considerably disappearing from the area of the CR.
\end{abstract}

Key words: checklist, Cyanobacteria, list of species, Czech Republic

\section{Introduction}

Local floras and faunas are usually not in the scope of the top science but still are important for several reasons. 1) They summarize knowledge of particular group of organisms in particular time and space, and preserve such information for future; 2) They are an information source for specialists from nature conservation and environment monitoring agencies, or for applied, especially hydrobiological and ecological research; 3) They make scientific knowledge more accessible for higher education and public.

This topic naturally also includes floras of Cyanobacteria and algae from various regions in spite of the larger geographic areas of their distribution. Such organisms have usually very distinct ecology and are specific for various habitats. They have (mostly) small size, but their significance for people and environment is often larger than the importance of macroscopic organisms, particularly in the case of their massive development. Except of the large monographs, such as Süsswasserflora von Mitteleuropa series, many local cyanobacterial floras were published recently, e.g. floras of Slovakia (MARHOLD \& Hindák 1998), Israel (Nevo \&Wasser 2000), Sweden (Willén 2001), Poland (Siemińska \& Wolowski 2003), Romania (CARAus 2003),
Ukraine (TsARENKO et al. 2006), Slovenia (VRHOVŠEK et al. 2006), and Netherlands (JoOsteN 2006).

At present, knowledge of diversity and distribution of Cyanobacteria within the Czech Republic is still very inconsistent. Information on historic distribution is available in works by HANSGiRg (1892), Lhotský \& Rosa (1955), and PoulíčKOvÁ et al. (2004). Hansgirg's study is very thorough and in his time very modern summary, based on author's long-term floristic research (with description of 85 new taxa), but the sampling was not performed in the whole area of the country and some parts were even omitted (e.g. whole Moravia, partially border areas). The checklist of LHotskÝ \& RosA (1955) is a summary of floristic work in Moravian-Silesian area to the middle of last century. The work of PouLíčKovÁ et al. (2004) is a large summary of the distribution data taken from almost all phycological works published between 1892 and 1998 from the whole Czech Republic. However, this summary also does not provide complete list of recent cyanobacterial flora, and besides, it contains multiple cases of synonymous names and unrevised or absolutely unclear species. It lists all findings that have been published, which in conclusion means just a part of the actually existing ones as well as some questionable data. 
Similar is the situation of a checklist included in the ARROW (Assessment of and Reference Report of Water Monitoring; MARVAN 2006), a website gathering information for water quality monitoring. It contains approximately 1400 cyanobacterial taxa, from which a large number of species actually does not occur in the area of the Czech Republic (e.g. marine species Nodularia baltica, Phormidium bulgaricum, Oscillatoria lloydiana, Pseudophormidium battersii, Blennothrix brebissonii, Pleurocapsa concharum, Aphanocapsa reinboldii and others; tropical species Eucapsis parallelepipedon, Anabaena bornetiana etc.). Moreover, several important recently published works solving numerous nomenclatural problems (e.g. KOMÁREK \& Anagnostidis 2005, Joosten 2006) are not reflected in this program, therefore many names are not valid.

The aim of this study is to create a real list of recent cyanobacterial taxa inhabiting the area of the Czech Republic based on modern taxonomic revisions and using relevant nomenclature, ecological evaluation of the individual taxa and monitoring of the abundance of each species.

\section{Methods}

The data for this study were collected from longterm results of determinations of samples collected from all biotopes and geographical areas of the Czech Republic by the author team, supplemented with floristic comments by some other colleagues (see Acknowledgements), and from published works with photographic documentation (HINDÁK 2008, ZNACHOR 2008). For synopsis and conciseness, the data concerning the type of habitat, life strategy, and abundance were summarized into categories; the overview including abbreviations is given in Table 1. The list contains taxa, in which we are sure of their recent presence in the $\mathrm{CR}$ as well as taxa, which were credibly proved to the area, but were not found for more than 50 years (marked with asterisk).

On the contrary, the list does not include elsewhere represented taxa such as:

- species, which were not validly published and nobody used the name thereafter (e.g. Synechococcus euryphyes Beck-Mannagetta, Synechococcus tumidus Rabenhorst, Nodularia aerophila BRABEZ);

- species, of which the description is insufficient, or with the original meaning of the description vague. These species are in modern literature designated usually as unclear taxa (e.g.. Chroococcus bituminosus (Bory) HANSGiRG, Nostoc fonticola
BRABEZ etc.);

- species, whose occurrence in the CR is possible, but was not confirmed yet (e.g. Oscillatoria jenensis, living in greenhouses in neighboring countries; tiny planktonic species reported from Slovakia Cyanogranis libera, Lemmermanniella flexa etc. (HINDÁK 2008));

- species, whose occurrence in the CR was previously reported, but from the ecological standpoint their presence is almost impossible (eg. tropical Nostochopsis lobatus).

The nomenclature and synonymy used in this study was derived from works of ANAGNOSTIDIS \& KOMÁREK 1990, KomÁrek \& AnAgnostidis 1989, 1998, and 2005 and an aggregate database CyanoDB (KoMÁREK \& HAUER 2010); partially also from less detailed AlgaeBase (GuIRY \& GuIRY 2010). These basic sources were supplemented with taxonomic studies on particular genera: RAJANIEMI et al. (2005), JOOSTEN (2006), Siegesmund et al. (2008), WACKLIN et al. (2009), ZapomělovÁ et al. (2009) and HašLer \& PoulíčKovÁ (2010).

\section{Results}

A total 505 species were found in the area of the CR; from which 392 were obviously recently present and 113 was validly documented in past, but their occurrence in present is unknown (Table S1). Several other cyanobacterial taxa, in which only generic assignment is known, were reported from the $\mathrm{CR}$ in addition to species included in the list. This is a case of Brasilonema sp., a pantropical genus (FIORE et al. 2007), whose unspecified representative is frequently found in tropical greenhouses and cooling towers; or e.g. planktonic cyanobacterium Eucapsis cf. densa (true E. densa is tropical species), Fischerella sp. from mine-tailings, Mantellum sp. from aquaria, Porphyrosiphon sp. from wetlands, and Stanieria sp. from greenhouses.

\section{Discussion}

At present, 392 cyanobacterial species inhabit the area of the CR, from which 157 are coccoid forms, 132 are simple filamentous forms, and 103 belong to the heterocyte-forming groups.

Compared with some other geographically and climatically similar countries (e.g. Slovakia, Slovenia), the CR lacks some biotope types such as alpine ecosystems, naturally including alpine 
Table 1. Typification of habitats, life strategy, and abundance.

\begin{tabular}{|c|c|}
\hline Abbreviations & Type of habitat \\
\hline HF & hypertrophic fishponds \\
\hline ME & mesotrophic-eutrophic stagnant waters (ponds, reservoirs) \\
\hline M & mesotrophic stagnant waters, reservoirs \\
\hline OS & oligotrophic stagnant waters: mountain lakes, quarries \\
\hline OR & oligotrophic (mostly mountain) running waters \\
\hline LR & lowland rivers \\
\hline $\mathrm{W}$ & wetlands, pools, furrows, usually with water plants \\
\hline PB & peat bogs \\
\hline $\mathrm{S}$ & soil, soil surface \\
\hline A & aerophytic, wet walls \\
\hline $\mathrm{AC}$ & aerophytic, calcareous \\
\hline AA & aerophytic, acidic (granite, sandstone) \\
\hline $\mathrm{AB}$ & aerophytic, serpentine or other ultrabasics \\
\hline $\mathrm{TH}$ & thermal springs \\
\hline SH & saline habitats \\
\hline \multirow[t]{2}{*}{ G } & glasshouses \\
\hline & Type of life strategy \\
\hline $\mathrm{p}$ & planktonic \\
\hline$b$ & benthic \\
\hline el & epilithic \\
\hline ep & epiphytic \\
\hline $\mathrm{m}$ & metaphytic/ periphytic \\
\hline \multirow[t]{2}{*}{ eg } & endogloeic \\
\hline & Abundance \\
\hline $\mathrm{D}$ & dominant species \\
\hline $\mathrm{F}$ & frequent \\
\hline $\mathrm{C}$ & common \\
\hline $\mathrm{R}$ & rare \\
\hline VR & very rare \\
\hline $\mathrm{DD}$ & data deficient \\
\hline
\end{tabular}

wet-wall flora, plankton and benthos of alpine lakes, and kryoseston. Due to the fact that the only one thermal spring in quite ruderal condition has been preserved (Karlovy Vary), the CR possess noticeably poorer thermal flora. On the other hand, floras of the rest of the biotopes are significantly more species-rich. However, this can be a consequence of an extensive determination effort of some working groups in the CR and may not actually reflect the real situation.

There were a total of 505 taxa of Cyanobacteria reported from the Czech Republic before intensification of agriculture and industry in the middle of the $20^{\text {th }}$ century. Nowadays, $22 \%$ of these taxa became extinct, which is significantly more than in other groups of autotrophic organisms. The decrease of the diversity was reported to be $10 \%$ in mosses (KUČERA \& VÁŇA 2005), and about $3,5 \%$ in higher plants (Holub \& ProchÁzKA 2000). The logical conclusion would be that eutrophication of our waters and modification of the overall landscape water regime affected the species richness of Cyanobacteria more than the richness of the other groups of organisms. However, it is necessary to realize that acquiring the data on macroscopical organisms is generally easier, as well as it is likely that we just do not know the refugia of many of the Cyanobacteria 
missing in the record. The amount of data on the cyanobacterial species distribution is increasing; therefore there is a higher chance to discover the missing records or even new species to the area.

The rate of endangerment of each particular taxon is hard to define, although the overall trend is clearly visible - if the biotope of the occurrence is endangered, the Cyanobacteria dependent on this biotope are also endangered. Besides the specific case of thermal Cyanobacteria, a negative impact can be seen particularly in species of oligotrophic standing waters - some previously abundant species have disappeared (typical is e.g. Gloeotrichia natans, Gloeotrichia pisum, or Nostoc kihlmanii etc.). Also halophilic biotopes and Cyanobacteria inhabiting them are considerably threatened. In case of species from oligotrophic running waters, the situation is not that conspicuous (alpine rivers and streams are mostly located within the preserved areas), yet, some species of these biotopes have not been found in the CR for a long period of time (e.g. Homoeothrix juliana).

Presence of non-indigenous species (marked as ALIEN in Tab. 2) in the CR is not as noticeable to date, as only small number (10) of species with low abundance has been reported (KAŠTOVsKÝ et al. in press).

\section{Acknowledgements}

We thank Jiří Heteša, Jarka Komárková, Alena Lukešová, Petr Marvan, and Eliška Zapomělová for helpful comments and for providing certain data. We thank Markéta Krautová for language correction. This study was supported by MSM 6007665801 and GAČR 206/08/0318 grants.

\section{References}

Anagnostidis, K. \& KomÁreK, J. (1990): Modern approach to the classification system of Cyanophytes 5: Stigonematales. - Arch. Hydrobiol./Algol. Stud. 59: 1-73.

Caraus, I. (2003): Algae of Romania: A distributional checklist of actual algae in Romania. - http://www.algaebase.org/pdf/ AC100CF00c67724FF3JrtnF0DE9B/Algae of_Romania_v2.0.pdf.

Fiore, M.F., SAnT'AnnA, C.L., Azevedo, M.T.P., KomÁreK, J., Kaštovský, J., SuleK, J.\& Lorenzini, A.S. (2007): The Cyanobacterial genus Brasilonema gen.nov., a molecular and phenotypic evaluation 1. - J. Phycol. 43: 789-
798.

Guiry, M.D. \& Guiry, G.M. (2010): AlgaeBase. Worldwide electronic publication, National University of Ireland, Galway. http://www.algaebase.org.

HAnsGirG, A.(1892): Prodromus českých řas sladkovodních, díl druhý. Archív pro přírpodovědecký výzkum Čech, díl VIII., č. 4 (botanické oddělení). - 182 p., Fr. Řivnáč - E. Grégr, Praha.

Hašler, P. \& PoulíčKovÁ, A. (2010): Diversity, taxonomy and autecology of autochtonous epipelic cyanobacteria of the genus Komvophoron (Borziaceae, Oscillatoriales): a study on populations from the Czech Republic and British Isles. - Biologia 65(1): 7-16.

Hindák, F. (2008): Colour Atlas of Cyanophytes. - 253 p., VEDA, Bratislava.

Holub, J. \& ProchÁzKa, F. (2000): Red list of the flora of the Czech Republic (state in the year 2000). - Preslia, Praha, 72(2-4): 187-230.

Joosten A.M.T. (2006): Flora of the blue-green algae of the Netherlands I: The non-filamentous species of inland waters. - 393 p., KNNV Publishing, Utrecht.

Kaštovský, J., Hauer, T., Mareš, J., Krautová, M., Bešta, T., Komárek, J., Desortová, B., Heteša, J., Hindáková, A., Houk, V., Janeček, E., Kopp, R., Marvan, P., Pumann, P., Skácelová, O. \& ZAPOMĚLOVÁ, E. (in press): A review of the alien and expansive species of freshwater cyanobacteria and algae, a case study from the Czech Republic. - Biol. Invasions subm.; DOI: 10.1007/s10530-010-9754-3

KomáreK, J. \& Anagnostidis, K. (1989): Modern approach to the classification system of Cyanophytes 4: Nostocales. - Arch. Hydrobiol./ Algol. Stud. 56: 247-345.

KomÁreK, J. \& Anagnostidis, K. (1998): Cyanoprokaryota 1. Chroococcales. - In: ETTL H., Gärtner G., Heynig H. \& Mollenhauer D. (eds): Süsswasserflora von Mitteleuropa 19/1. 548 p., Gustav Fischer, Jena-Stuttgart-LübeckUlm.

KomÁreK, J. \& Anagnostidis, K. (2005): Cyanoprokaryota 2. Oscillatoriales. - In: BÜDEL, B., Krienitz L., GÄrtner G. \& Schagerl M. (eds): Süsswasserflora von Mitteleuropa 19/2. 759 p., Elsevier/Spektrum, Heidelberg.

Komárek, J. \& Hauer, T. (2010): CyanoDB.cz - Online database of cyanobacterial genera. - Wordwide electronic publication, Univ. of South Bohemia \& Inst. of Botany AS CR, http://www. cyanodb.cz.

KuČERA, J. \& VÁŇA, J. (2005): Seznam mechorostů a Červený seznam mechorostů ČR (2005). Př́roda, Praha, 23: 1-104.

Lhotsкý, O. \& Rosa, K. (1955): Soupis Moravskoslezských sinic a řas. - 259 p., ČSAV 
Praha.

Marhold, K. \& HindÁK, F. (1998): Checklist of nonvascular and vascular plants of Slovakia. -687 p., VEDA, Bratislava.

Marvan, P. (2006): Taxalist organismů fytobentosu (ale i fytoplanktonu). http://www.ochranavod. cz/index.php?\&click=T0703\&T0905=1\&T07= $1 \& \mathrm{~T} 0703=1 \& \mathrm{~T} 0702=1 \&$ click=T0702.

Nevo, E. \& WAsser, S.P. (2000): Cyanoprokaryotes and Algae of Continental Israel. - 629 p., A.R.A. Gantner Verlag K.G., Ruggell/ Liechtenstein.

PoulíčKová, A.,LhotskÝ, O. \& Dřímalová, D. (2004): Prodromus sinic a řas České Republiky. - Czech Phycology 4: 19-33.

Rajaniemi, P., Hrouzek, P., Kaštovská, K., Willame, R.,Rantala, A., Hoffmann, L., Komárek, J. \& Sivonen, K. (2005): Taxonomic consequences from combined molecular and phenotype evaluation of selected Anabaena and Aphanizomenon strains. - Arch. Hydrobiol./ Algol. Stud 117 (Cyanobacterial Research 6): 371-391.

SiemińskA, J. \& Wolowski, K. (2003): Catalogue of Polish Prokaryotic and Eukaryotic Algae. 251 p., W. Szafer Institute of Botany, Polish Academy of Science, Kraków.

Siegesmund, M., Johansen, J.R., Karsten, U., FRIED,L T. (2008): Coleofasciculus gen. nov.
(Cyanobacteria): Morphological and molecular criteria for revision of the genus Microcoleus Gomont. - J. Phycol. 44: 1572-1585.

Tsarenko, P.M., Wasser, S.P. \& Nevo, E. (2006): Algae of Ukraine, Vol.1. - 713 p., A.R.A. Gantner Verlag K.G., Ruggell/ Liechtenstein.

Vrhovšek, D., Kosi, G., Krivograd-Klemenčıč, A. \& Smolar-Žanut, N. (2006): Monograph on freshwater and terrestrial algae in Slovenia. - 172 p., Limnos and ZRC Publishing, Ljubljana.

Wacklin, P., Hoffmann, L \& Komárek, J (2009): Nomenclatural validation of the genetically revised cyanobacterial genus Dolichospermum (RALFS ex BORNET et FLAHAULT) comb. nova. - Fottea 9(1): 54-64.

WiLlén, E. 2001: Checklist of Cyanobacteria in Sweden. - 71 p., ArtDatabanken, Uppsala.

Zapomělová, E., Jezberová, J., Hrouzek, P., Hisem, D., ŘehÁková, K. \& Komárková, J. (2009): Polyphasic characterization of three strains of Anabaena reniformis and Aphanizomenon aphanizomenoides (cyanobacteria) and their re-classification to Sphaerospermum gen. nov. (incl. Anabaena kisseleviana). J. Phycol. 45: 1363-1373.

ZnACHOR, P. (2008): Fytoatlas. - http://www. fytoplankton.cz/fytoatlas.php.

(C) Czech Phycological Society

Received January 25, 2010

Accepted April 6, 2010

Supplementary material

the following supplementary material is available for this article:

Table S1. List of Cyanobacteria from Czech Republic.

This material is available as part of the online article (http://fottea.czechphycology.cz/contents) 